日本平滑筋誌（Jap. J. Smooth Muscle Res. ), 9, 1-8, 1973.

\title{
カエルの嘔吐時に見られる奇異な現象, 食道・胃の反転脱出
}

\author{
川崎医科大学 生理学教室 \\ (主任：福原 武教授) \\ 福原武, 内藤富夫, 亀山博子
}

\section{A PECULIAR PHENOMENON, THE PROLAPSUS OF THE ESOPHAGUS- STOMACH, OBSERVED IN THE VOMITING OF THE FROG}

Takesi Hukuhara, Tomio NaItoh and Hiroko Kameyama

Department of Physiology, Kawasaki Medical College, Kurashiki, Japan

(Director: Prof. Dr. T. Hukuhara)

(1) When in frogs, Rana nigromaculata and Rana catesbeiana, the mucosa close to the aditus laryngis as well as to the esophageal opening was gently stroked with a piece of absorbent cotton, there occurred abrupt and powerful contractions of the abdominal muscles, being accompanied with the prolapsus of both esophagus and stomach into the mouth wide open. As regard to the gastric motility neither augmentation nor inhibition was to be seen.

The mechanism of the prolapsus may be as follows: At first the contractions of the abdominal muscles produce a sudden rise of the abdominal pressure and this then forces the stomach upwards into the esophagus, until both esophagus and stomach are turned inside out.

From the results described above, it may be concluded that in the frog the abdominal muscles play a major role in the vomiting, whereas the stomach has no active concern with it.

(2) When $0.5 \mathrm{ml}$ (Rana nigromaculata) or $5 \mathrm{ml}$ (Rana catesbeiana) of the tartar emetic-Ringer solution whose concentration of the emetic was $0.05 \mathrm{~g} / \mathrm{ml}$ were introduced into the stomach, not only the prolapsus but also the excitation of the movements of the stomach was elicited. The latter phenomenon should be attributed to the drug action upon the neuro-muscular apparatus of the stomach, because upon the stomach of the pithed frog the drug also exerted the excitatory action similar to that observed in the intact frog.

緒

哺乳類の嘔吐についての研究の歴史を概観する と, 胃内容の吐出に主役を演ずるのは, ある研究 者によれば，胃の収縮増強であり，ある人々によ れば，呼吸筋による腹圧の上昇である，その歴史 は Hukuhara ら (1957) $\left.{ }^{5}\right)$ おょび大橋 $(1968 \mathrm{a}$, b) ${ }^{9,10)}$ の論文中に簡潔に述べてるが，彼らの研 究によって得られた結果を総合すれば, 嘔吐現象 は次のようなものである。

\section{言}

すなわち，イヌやネコにおらいては，吐出は主と して，吸息筋および呼息筋の異常に強い同時収縮 によってひき起てされるものであり，まず幽門部 が持続収縮に抢ちいるとともに，胃体部抢よび噴 門部か球状に膨れる。ついで吸息筋おらよび呼息 筋, 言いかえると, 横隔膜と腹筋の急激かつ強烈 な同時収縮が起とるととによって，初めて胃内容 が吐出される．胃内容の吐出で主役を演ずるの 
は，呼吸筋なのである。

哺乳類以外の動物の嘔吐についての研究はまて とに乏しい.ととに両棲類については, Mellinger $(1881)^{7)}$ の研究と, 乙の研究の追試が, Thumas (1891) ${ }^{11)}$ の教室で Gruzewski によって行なわれ たにすぎない. Mellingerによると，吐酒石を胃 中，静脈内，リンパ腔内に投与すると，胃の幽門 部に律動的に收縮が起とり，てれが逆行して，つ いには内容の一部を，食道を通してロ中に吖出す
る。そして彼は，乙の現象は，両側の迷走神経を 切断した後にも，ひき起てされるから，ての動物 では，いわゆる嘔吐中枢に無関係に嘔吐が起とる のだと考えた。これによれば，呼吸筋，特に腹筋 は何らの役割も演じないとみなされる。しかし果 して嘔吐の機序が哺乳類と両棲類とで全く異なる ものであろうか。私どもはての点を明らかにする ために, 次の研究を企図した。

\section{実験 方 法}

実験材料として，体重 7.0〜 78.5g のトノサマ ガエル Rana nigromaculata 約 110 個体, 体重 380〜550g のウシガエル Rana catesbeiana 約 60 個体を，すべて無麻酔で用いた。トノサマガエル としては，捕獲したばかりの新鮮なものを用い， ウシガエルには毎日約 5 10g の牛肝蔵を餌とし て与え，栄湌状態をよくして用いた。実験期間は 1972 年 6 月から同年 9 月であり, 実験 時の気温 は，27.0〜31. $0^{\circ} \mathrm{C}$ であった。

まず，左手の親指と中指とで動物の腸骨を背側 からつかみ，尾骨を薬指で支えるととによって固 定した後，ピンセットで口を扮し開き，喉門また は食道入口をピンセットあるいは, 小綿塊で軽く 摩擦するととによって機械的に刺激した。あるい は，化学的刺激として，吐剤を用い，乙れを口， 食道を通して胃内に注入するてとによって嘔吐を ひき起しさせた。薬物投与の場合には，動物をガ ラス鐘中に抢いて, その行動を観察した。吐剤と しては, 吐酒石（酒石酸アンチモニルカリウム, $\mathrm{C}_{4} \mathrm{H}_{4} \mathrm{KO}_{7} \mathrm{Sb} \cdot \frac{1}{2} \mathrm{H}_{2} \mathrm{O}$ ，大阪キシダ化学製） $0.05 \mathrm{~g} /$ $\mathrm{ml}$ Ringer 溶液を用いた。

つぎに，嘔吐時に胃がいかなる運動を呈するか を知るために，前述の機械的刺激によって，嘔吐 現象が現われるや否や，沸騰中の湯に，てのカエ ルを投じて，1２分間熱湯固定した後， $80 \%$ 工 チルアルコール中に保存, このようにして作った カエル標本の腹腔を開き，胃の状態を観察した。 他方, 動物を背位に固定し, 腹腔を広く切開し て, 食道, 胃を観察しながら, 上述の機械的ある いは化学的刺激によって, 嘔吐を起てさせ, その
際の胃の状態を観察した。胃運動記 録のために は, 必要に応じて, motor drive camera (キャ) ン製カメラ F-1 招よび motor drive unit）を用 いて，0.5〜 秒間隔で，胃の写真撮影を行ない, ときには胃の一局所をセルフィンでつまみあげ, てれをひずみ計 force displacement transducer （日本光電製 $\mathrm{FD}$ ピックアップ SB-1 TH） を介 して,インク書きオシログラフに接続して，運動 を描記した。また嘔吐時における腹筋の役割を明 らかにするために, 腹直筋 M. rectus abdominis の筋電図を描記した。

まず中央に小円孔を穿がった固定板の小孔の上 にカエルを腹位にしてのせ, 四肢を軽く固定板に 縛りつけた。乙の状態で腹部中央部の皮膚を小円 状切除し, 腹直筋の一部を露出し, この筋を釣 針型細小電極でひっかけ，前述の固定板に穿がた れた小孔を通じて, 生体電気増幅器に連結し, 不 関電極としては， $0.5 \times 2.5 \mathrm{~cm}$ の長方形の白金電 極を大腿皮下に插入固定した。同時に電極近くの 筋をセルフィンで摘み，乙れを木綿糸を介してひ ずみ計（日本光電製 $\mathrm{FD}$ ピックアップ $\mathrm{SB}-1 \mathrm{~T}$ ) 記録器に連結し, 腹直筋の収縮を併記した。さら に，動物には長い細糸をつけた小肉片を，あらか しめ慨として与えた. 給慨後 5〜15 分には, 肉片 は胃の上部または中間部に達している。なおての 肉片にむすびつけた糸の端を，ひずみ計に連結す るととによって胃内容の脱出時点を記録した。ま た, 嘔吐をひき起てすには, 濃度 $0.05 \mathrm{~g} / \mathrm{ml}$ の吐 酒石 $0.5 \mathrm{ml}$ を胃内に注入した。 に導き，ついでてれを歪用前置増幅器およびペン 


\section{実験}

\section{1. 喉門刺激による食道・胃の脱出}

トノサマガエル 30 個体, ウシガエル 20 個体に おいて，はとんど同様な嘔吐現象がひき起てされ る.

方法の項で述べたようにして，動物を固定した 後, 口腔を開いて, 喉門および食道開口附近に機 械的刺激を加えると，例外なく次のような現象が ひき起てされた。すなわち，口が大きく開かれる と同時に, 突然食道, ついで胃が裏返しになって 出てきた。図 1 および 2 は，それぞれ胃の口中へ の反転, 脱出過程, 乃至は脱出した状態を示すも のである. 胃に内容があれば，内容が勢いよくロ 外に吐き出された。乙の刺激から反転脱出までに 経過する時間は長くても数秒以内であった，食道 および胃の脱出は，早いときには，すぐつぎの瞬 間にもとに戻るが，多くの場合には数秒間脱出し ておった。

上述の吐出が，どのようにしてひき起てされる かを知るために，まず方法の項で述べたように， 脱出した状態で, 熱湯固定した多数の標本で, 胃 の状態を観察した。乙れによると図 3 に示すよう に，すべての例に扔いて，胃が食道中に嵌入して いるととがわかった。そして嵌入が深いならば深 いはど，脱出が顕著となった。たとえば図 $3 . b-1$ に示すように，胃の上端部がわずかに食道中に嵌 入している場合もあり, 図 $3 . b-2$ 亿示すように, 胃中央部までが嵌入しているとともあり, 図 3. b-3に示すように，胃のはとんど全部が嵌入して いるとともあった。さらに甚だしい場合には，図 3. b-4 亿示すように，胃だけでなく十二指腸もか なりの長さにわたって嵌入していた。また食道,

胃の強い反転・脱出時には, 食道・胃の裏面にま で，膨らんだ肺，ときには卵巣の一部までも嵌入 しておら，てれが食道・胃の脱出部が時に著しく 膨大する原因となっていると考えられる。

\section{2. 吐剤による食道・胃の脱出}

嘔吐が吐剤によってひき起てされた場合にも， 両種のカエルにおらいて，機械的刺激によってひき 起てされた場合と全く同様の吐出現象が認められ た。

吐酒石 $0.5 \mathrm{ml}$ をトノサマガエルの胃内に注入 すると，32例において例外なく胃の内容吐出がひ

\section{結果}

き起てされた，注入してから，胃の反転および胃 内容の吐出がひき起てされるまでに経過する時間 は，個体によって異なり，短いもので 5 分，長い もので 48 分を要しているが，大部分の例 (25 例) では, 10〜20 分であり, 体重の重い大きい個体は ぞ，嘔吐までに長時間を要した。なお，吐酒石を 与えた個体は，投与後約 1 時間半から 13 時間ま での間に，すべて死亡した。ウシガエルにおらて は，1個体あたり $5 \mathrm{ml}$ の吐酒石を，口・食道を 通して胃に注入した。乙の場合には，吐酒石投与 後 1 時間から 3 時間半の間に， 5 例中 5 例とも胃 内容の吐出を示した。 またてのカエルでは，投与 後 24 時間から 72 時間の間に，すべて死亡した。

\section{3. 食道・胃脱出の機序}

それでは食道・胃脱出の原動力は何であろう か. 観察によると, 脱出時には顕著な下腹部の筋 の収縮がひき起てされた。このととは, 下腹部の 筋の収縮が腹圧を高め, その結果として，胃の食 道中への嵌入がひき起てされるととを示唆する。 てれに関連して興味があるのは，前脳から小脳， 延髄までを除去するてとによって，嘔吐中枢を除 外した動物, あるいはさらに，脊髄をも破壊した 動物において；下腹部を手で圧迫するてとによっ て腹圧を十分にたかめればたやすく胃の嵌入が起 こることである.

嘔吐の場合にひき起てされる食道・胃の脱出が

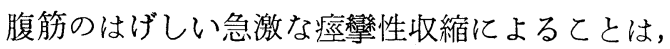
観察によってもわかるが，腹筋からの筋電図を描 記すると，いっそう明瞭となる (図 $4 \mathrm{a}, \mathrm{b}$ ). 図 $4 \mathrm{a}$, b は，吐剂を与えたトノサマガエルの腹直筋から 得られた筋電図およびその筋収縮を示したもので あるが，胃の反転・脱出, 胃内容の口外への吐出 と同時に突如としてスパイク放電群が現われる.

つまり, 嘔吐に筋の激しい収縮が関与するてとが 示されている，胃内容がでく少ない場合には，筋 電図の発生は一過性で, 胃内容の吐出とともに停 止したが (図 4 a), 胃内容の多い場合, または胃 内容が一挙に吐出されなかった場合には，1秒か ら 10 数秒間隔で, 筋電図の発生が繰り返され, 10 回以上に及ぶことがあった（図 4 b). ての連 続発生の場合には, 筋電図は依然として力強いて ともあれば，回を重ねるでとに，次第に減衰する 
とともあった。なお内容吐出がひき起てされる以 前に弱い筋電㘠（嘔吐時の大きさの約 $1 / 3 \sim 3 / 5$ ) がたびたび認められたが，てれは眼を閉じたり， 頭在低めるなどの悪心現象々一致して見われた。

上述のととから，食道・胃の脱出には，胃の収 縮は不必要であると考えられる。これを確かめる ために，腹腔死開いて食道招よび胃を観察した が，すべての例（20例）に扔いて，嘔叶時に胃に は特別の運動変化侍認少られなかった。

以上のととから，雨棲類の嘔叶に際しての食 道，胃脱出の機序は，つざのようなものであると 考えられる。すなわち，正常動物に抢いては，嘔 吖は，まず（a）喉閏・食道開口附近の刺激によっ て，嘔吐中枢を介してひき起こされるものであ り，(b) 胃の脱出は，腹筋加强烈に収縮して腹性 を上暑させ，その結果として壁の姳く堅い胃が押 しあげられて，壁为薄く执がっている食道中に荻 入するためでる。

\section{4. 吐酒石の胃に及ぼす作用}

つぎに腹腔を開いて，胃の状態を觀察しなが ら，叶酒石 $0.5 \mathrm{ml}$ 支胃に注入すると，20例にお いて，例外なく胃の運動が高進する。もともと生 体内にあるとさは，室温 $31^{\circ} \mathrm{C}$ の場合，自発収縮 が 16 秒はどの周期をもって，胃の上端部に律動 的に発生し，幽門側に向って，減衰しながら云播 するととが多いが，ときには幽䅀部に発生し，減 衰しながら逆行し，中央部で消失するとともあ り，またまれには，ヒトの胃の角切痕に相当する 部位に收縮が発生し，口尾両侧に向って伝播する とともあった，薬物を胃に注入すると，上述の連 動か強められ，前よりも遠くまで伀播するように なった。

Goltz (1872) 2) 仗，迷走神経切断後には，長特 間にわたって（1日以上），胃連動の強い収縮が 続くというが (627 真)，私どもは福原 (1956)の 方法に従い, 左右の迷走神経を 10 例にわたって 切断したが，ついそそような現象に遭遇しなか った。切断後長時間（約 5 時間）経たものでは， 胃は普通よりも弛緩していた。私どもの結果が， Goltzのそれと一致しないのはなぜか，その理由 は不明である。また Goltz は，脳脊䯣破壊後にお いては，きわめて長時間にわたって胃運動の高進 が続くと言っているが(たとえば6日)，私ども の実験ではたかだか 5〜10 分間続くにすざなかっ
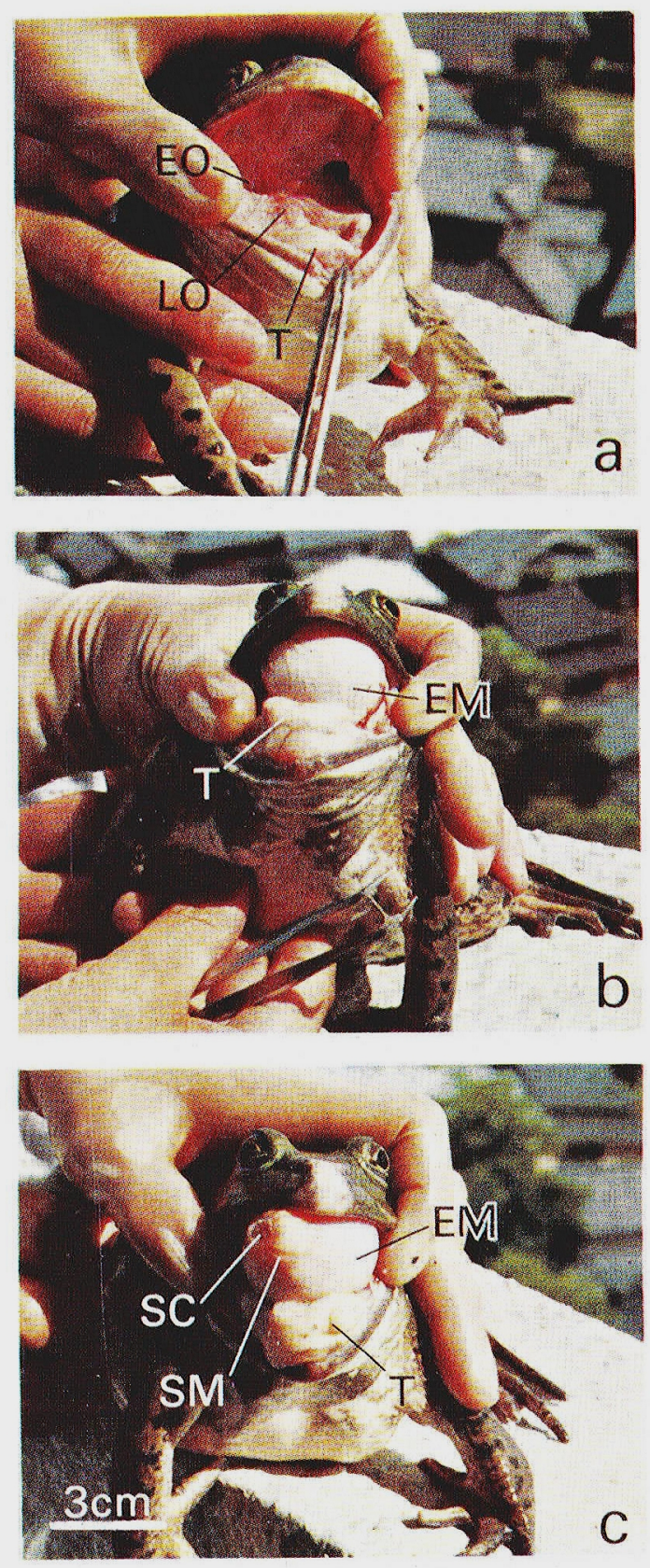

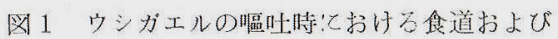
胃の口丩ヤの反転・脱出

(a) 口驾開き喉門または食道開口附近を小綿

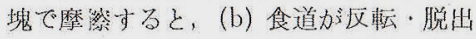
L, つで，(c) 胃の一部分汉転・脱出 す为.

LO：聅門 EO：食道開口 $\mathrm{T}$ ：舌

$\mathrm{EM}$ ：食道（祜膜） SM：置（粘膜）

$\mathrm{SC}$ ：胃内腔 

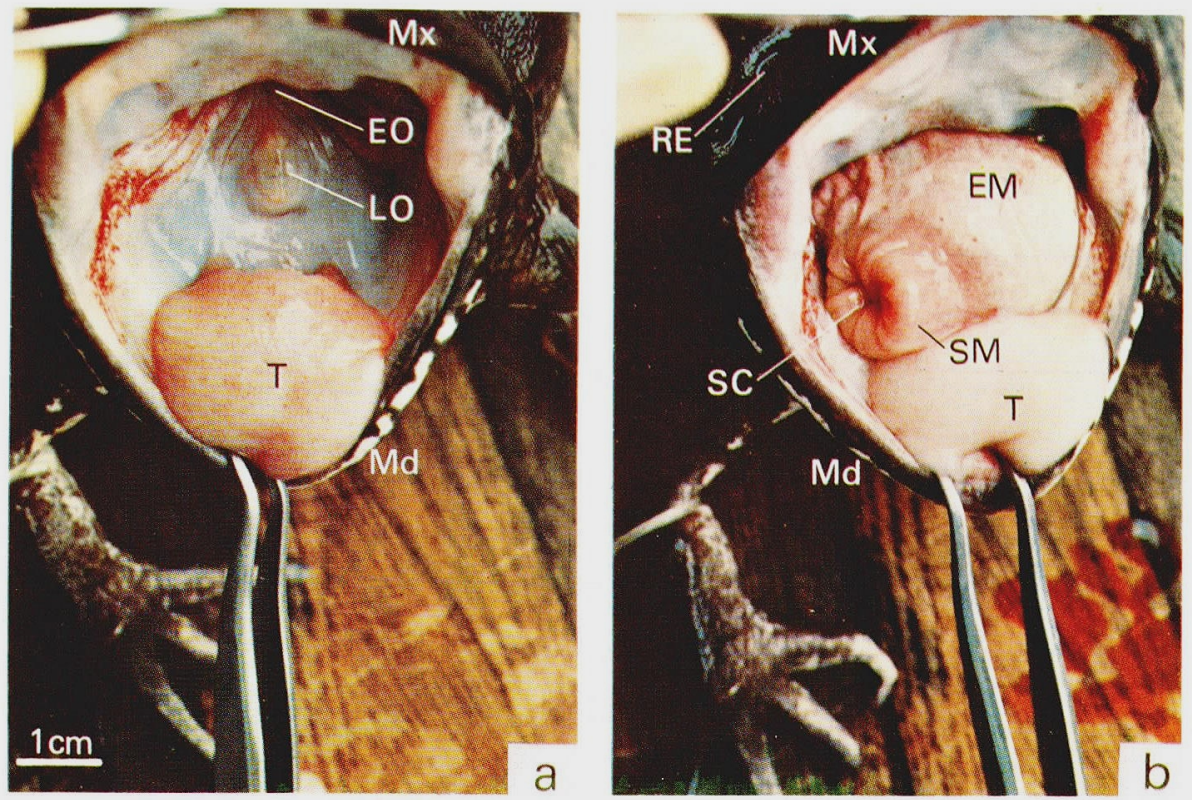

図 2 ウンガエルの踾吐時における食道および胃の口中への反転・脱出

(a)および (b) はそそれそれ図1の (a) と (c) に相当する状熊を示す.

$\mathrm{LO}$ ：搌閒 $\mathrm{EO}$ ：食道開口 $\mathrm{T}$ ：舌 $\mathrm{EM}$ ：俍道 (粘膜) SM：胃 (粘瞙)

$\mathrm{SC}$ : 胃内腔 RE：右眼 $\mathrm{Mx}$ ：上顎 $\mathrm{Md}$ ：下顎
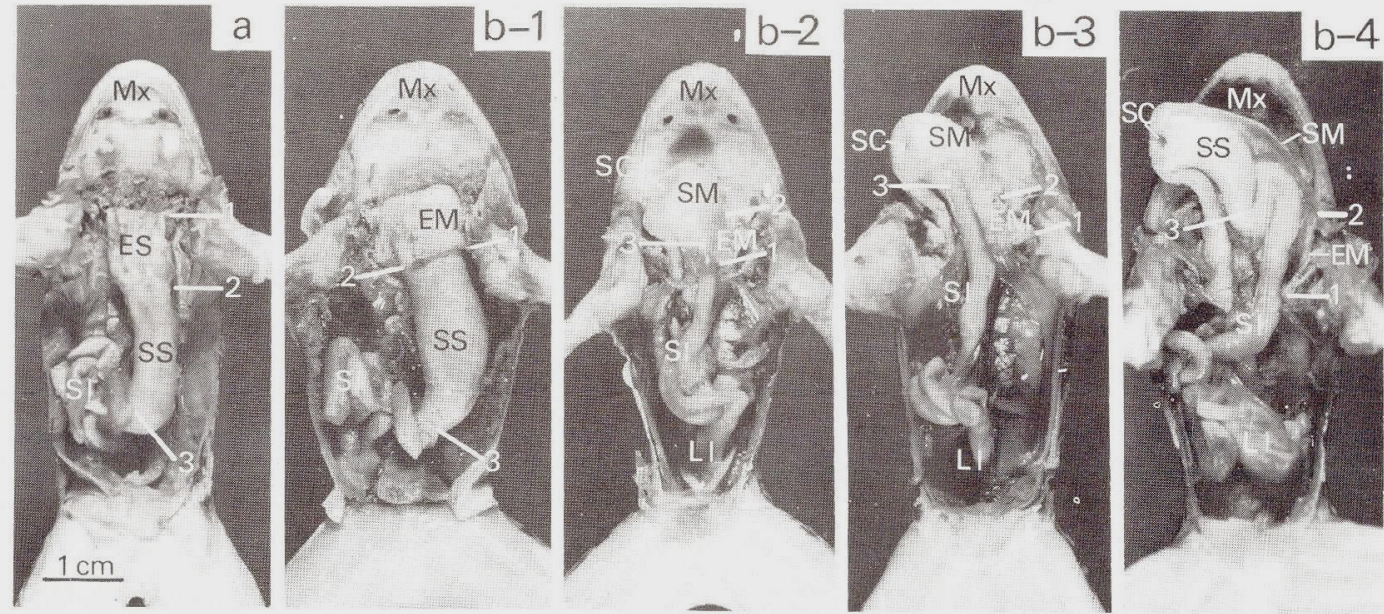

四 3 トノサマガエルの嘔吐時における食道・胃脱出の様相

ES：食道 (漿膜) EM：食道（粘膜） SS：胃 (獎膜) SM：胃 (粘膜)

$\mathrm{SC}$ ：胃内腔 SI：小腸 $\mathrm{LI}$ ：大腸 $\mathrm{Mx}$ ：上顎

1：食道入口 2 ：食道. 胃境界 3：幽門

た。またてれと间じような軏動高進が，胃のすべ ての自律神経，すなわち迷走父感神経幹および内 臓神経走画方とも切断した場命にも認められた。

支配神経の全部を欠く胃において，吖酒石の胃 内への注人は，無傷の場合と间様に胃運動の高進
をひき起とし，また胃の漿膜面に滴トすると，狊 内へ注入した場介よりも，顕著な漣動高進がひき 起こされた。

上述の結果から，吖酒石適用による胃連動の高 進は，嘔吖の一分象ではなく，との薬物が粘膜あ 

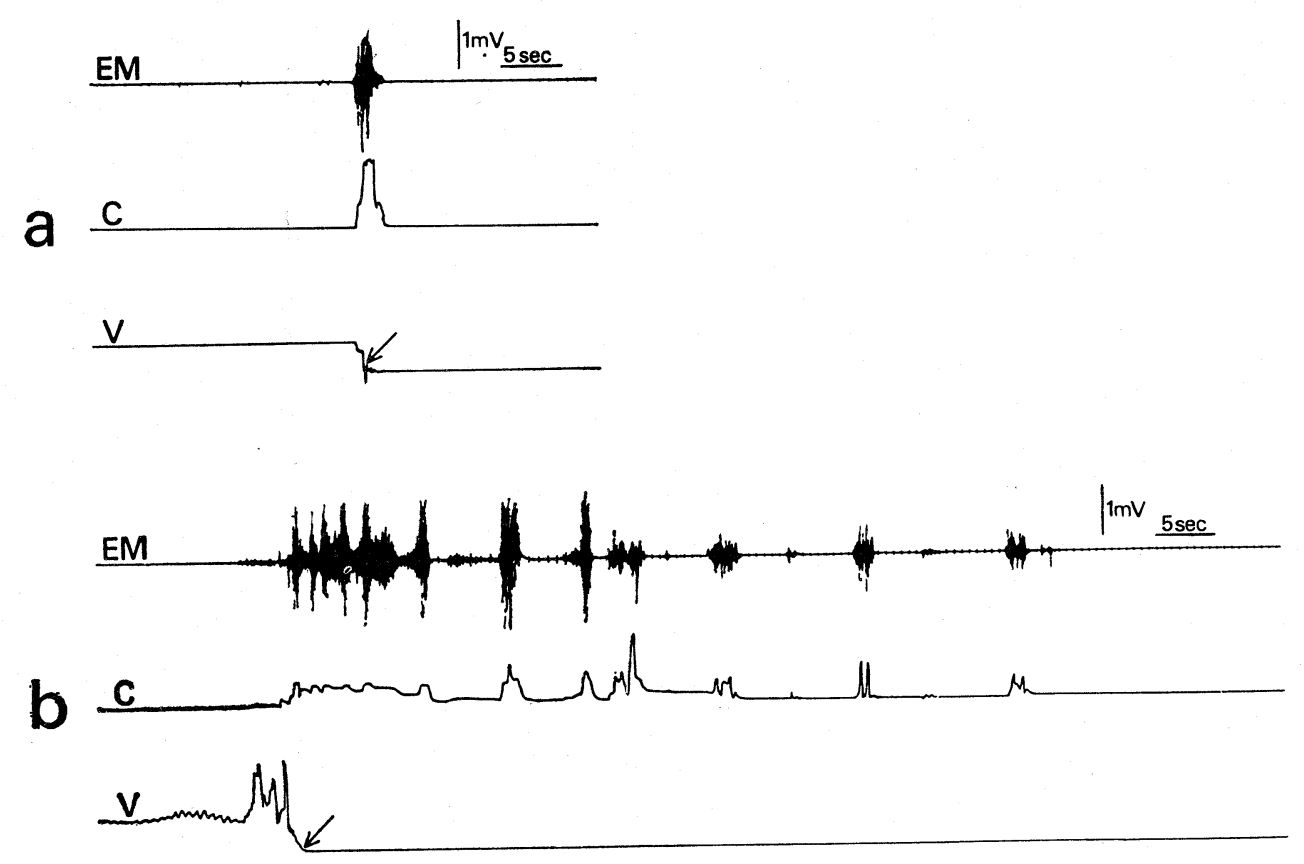

図 4 トノサマガエルの嘔吐時における腹直筋の筋電図 吐酒石の投与後, a では 6 分で, b では 48 分で嘔吐が起きた。

$\mathrm{EM}$ ：筋電図 $\mathrm{C}$ : 筋収縮 (上向きが収縮) $\mathrm{V}$ : 内容吐出の瞬間 (矢印)

るいは漿膜をと抢て，直接胃壁に働いた結果で あると考えるべきである．なおての薬物は，小腸 や大腸にも直接作用して，その軍動に著明な高進

\section{考}

私どもは，上述のように，自然の状態で，カエ ルの喉門・食道開口附近の粘膜を機械的に刺激す ると，腹筋が急に強縮をおこし，同時に大きく開 いた口腔中に胃が裏返しになって出てくるととを 見出した。私どもの観察によると, 嘔吐に際して 胃の運動には特別の変化が認められない, 故に嘔 吐が胃運動の増強によって起てるとは考えられな い. 腹筋の強い急激な収縮によって, 腹圧が高め られると, 堅く弾力性に富む胃が押しあげられ て, 壁が薄く拡がっている食道内に嵌入し, 逆行 性腸重積が起こると考える.

哺乳類では, 吸・呼両筋の同時収縮によって嘔 吐が起とるととを, Hukuhara ら (1957) ${ }^{5)}$ が確 かめたが，両棲類（カエル）でも腹筋を呼息筋の 一種と考えれば，呼吸筋が嘔吐では主役を演じて いるととになる。原理的には，哺乳類の嘔吐と同
をひき起とし，大腸でははとんど常に排便がひき 起てされた。

察

質のものと言うべきであろう.

哺乳類では, 大橋 $(1968 \mathrm{a})^{9)}$ の研究で明らかな ように, 嘔吐中枢の興奮が延髄・脊髄に存在する 胃腸運動の高進ならびに抑制核に及び，その総合 効果として，一般に強い運動高進が認められる.

私どもの研究結果によると，カエルではてのよう な現象は, 自然刺激すなわち喉門・食道開口附近 の刺激によっては, 認められなかった。吐酒石を 用いた場合には，胃の高進が認められるが，それ はこの薬物が直接胃の神経筋要素を刺激興奮させ るためである。カエルでは, 吐酒石は胃のみなら ず，小腸，大腸の運動をも高める．興奮性の高い 場合, 胃腸の緊張が極度に高まる結果として, 胃 ではその内容が食道から一部は口中へ押しあげら れ，大腸では排便がひき起てされた。

Mellinger (1881) ${ }^{7)}$ づいて Thumas (1891) ${ }^{11)}$ 
は，私どものように，喉門・食道開口附近の機械 的刺激を試みなかった。もっぱら吐剤, 特に吐酒 石を用いて研究をすすめている。乙のために胃の 運動の高進が実は吐酒石の作用であるととに気付 かず，ついに両棲類では嘔吐中枢なしに嘔吐が起 とるという結論に到達したのであろう。

なお Mellinger は，吐酒石適用によって胃に強 い逆蛙動が発生し，てれによって内容の一部がロ 中に押し出されると述べている。しかしての逆蠕 動は，吐酒石によってひき起てされる特殊効果で はない. すでに羽藤 (1958) 3) や Babkin (1924) ${ }^{1)}$ も言っているように，カエルの胃では，自然状態 におらてても，正蠕動のみならず逆蠕動がしばしば 認められるものである，Mellinger は,たまたま逆

\section{摘}

1. カエルの喉門・食道開口附近の粘膜を機械 的に刺激すると，腹筋が急に強縮を抢てし，口中 に食道己胃が裏返しになって出てくる。乙の際胃 の運動高進は，認められない。乙の口中への胃の 脱出の機序は，つぎのようなものであろう。まず 腹筋の強縮によって, 腹圧が突然に高まり, その 結果として胃が押しあげられ，ついに食道内に嵌 入するのである。乙のてとから，カエルにおらて は，嘔吐は胃の収縮によってではなく，全く腹筋

\section{文}

1) Babkin, B.P.: The influence of natural chemical stimuli on the movements of the frog's stomach. Quart. J. Exp. Physiol., 14, 259-277, 1924.

2) Goltz, FR.: Studien über die Bewegungen der Speiseröhre und des Magens des Frosches. Pflügers. Arch. Ges. Physiol., 6, 616$642,1872$.

3) 羽藤博鬼：カエルの交感神経交通 枝及び内藏神 経切断末梢端刺激の胃運動に及ぼす影響。日本 生理誌, 20, 388-396, 1958.

4) 福原 武: 生理学実験法, p. 122-124, 南山堂, 東京, 1956 .

5) Hukuhara, T., Okada, H. \& Yamagami, M.: On the behavior of the respiratory muscles during vomiting. Acta. Med. Oka-
蠕動の現われている胃に遭遇し，ての逆蠕動が吐 酒石によって高進したものと推測したのではなか ろうか. 哺乳類では, 正常胃の運動は蠕動であ り, 逆蠕動は認められない. その理由について は, 福原 $(1967)^{6)}$ の総説を参照されたい. 私ど もは，カエルで逆蠕動がしばしば認められるの は，乙の動物の進化段階では，まだ壁内神経細胞 が収縮波の方向調整機能を具えていないためであ

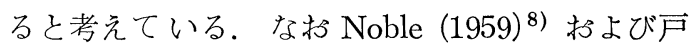
木田ら $(1955,1962)^{12,13)}$ は嘔吐に際して胃が裏 返しになって，口中に吐出されることを見たが， その際の腹筋や胃の状態については，言及しな かった。

\section{要}

の収縮によって起てるものと考えられる.

2. $0.05 \mathrm{~g} / \mathrm{ml}$ の濃度を有する吐酒石-Ringer 液の $0.5 \mathrm{ml（トノサマガエル）あるいは} 5 \mathrm{ml}$ (ウ シガエル）を胃内腔に注入すると，食道と胃の脱 出ばかりでなく, 胃の運動の高進が起てる，脳沓 髄破壞カエルでは食道・胃の脱出は起てらない が, 胃の運動高進効果は認められる. したがって ての高進効果は薬物が直接胃壁に作用してひき起 とされたものと考兄られる。

\section{献}

yama, 11, 117-125, 1957.

6) 福原 武 : 壁内神経細胞による 胃腸運 動調節の 機序. 日平滑筋誌, 3, 1-18, 1967.

7) Mellinger, C.: Beiträge zur Kenntnis des Erbrechens. Pflügers. Arch. Ges. Physiol., 24, 232-245, 1881.

8) Noble, G.K.: The biology of the amphibia. p. 202, Dover Pub. New York, 1959.

9) 大橋勝彦: 悪心, 嘔吐時の大腸および胆霊の運 動について. 日本生理誌，30，771-778，1968.

10）大橋勝彦：悪心，嘔吐時の胃および 小腸運動に ついて. 日本生理誌, 30, 736-750, 1968.

11) Thumas, L.J.: Ueber das Brechcentrum und über die Wirkung einiger pharmakologischer Mittel auf dasselbe. Arch. pathol. Anat. Physiol. Virchow's., 123, 44-69, 1891. 
（12）戸木田菊次, 岩崎 成, 油井房枝：ジキタリス 投与蛙の開口嘔吐及び其の作用 機転. 日本薬理 学雑誌, 49, 138-142, 1955.
13） 戸木田菊次 : 蛙の嘔吐と痔。カエル行状記，6879, 技報堂, 東京, 1962 .

(1972 年 10 月 2 日受付) 